\title{
FURTHER OBSERVATIONS ON FISH GROWTH IN A FERTILIZED SEA LOCH (LOCH CRAIGLIN)
}

\author{
By F. Gross, D.Sc. \\ Department of Zoology, University of Edinburgh
}

(Plate I and Text-fig. I)

In a previous paper (Gross, I947) an account was given of studies on fish growth in Loch Craiglin under conditions of fertilizer application in I942/43. From I944 onwards Drs Marshall and Orr continued to apply fertilizers of different kinds and in varying quantities, and investigated the subsequent growth of phytoplankton (Marshall \& Orr, 1948). The sampling of the bottom fauna and of the fish population was much reduced owing to our preoccupation with an experiment carried out in the open Kyle Scotnish (Gross, Raymont, Nutman \& Gauld, I946). However, analysis of the data obtained has established a few interesting points, briefly described here.

\section{GROWTH OF FLOUNDERS FROM I944 TO 1947}

At the end of 1943 the fish population of Loch Craiglin consisted of three stocks of flounders (Pleuronectes flesus):

Stock I, transferred to Loch Craiglin in July 1942 when the fish were a few months old (age-group O).

Stock II, transferred in April and May 1943 as I-year-old fish (Group I).

Stock III, transferred in July 1943 as group-O flounders.

Their size distibutions and mean sizes are given in Text-fig. I and Table I, which also contain the relevant data concerning the samples taken subsequently.

Comparison of the fish obtained in April 1944 with those from October and November 1943 gives no clear evidence of good winter growth such as was observed during the winter $1942 / 43$. The mean size of stock I increased by $3.3 \mathrm{~cm}$. (13\%), and $65 \mathrm{~g}$. ( $35 \%$ ), that of stock II by $\mathrm{I} \cdot 5 \mathrm{~cm}$. (9\%), and I $9.5 \mathrm{~g}$. ( $28 \%$ ), but the numbers involved ( 6 and 4 respectively) are too small to be of significance. The mean size of the sample of stock III flounders (75 specimens) was almost exactly the same as it was in November.

There is an indication of winter growth of stock III in the shift of the upper limit of range of size to $\mathrm{I}_{3}$ and I $4 \mathrm{~cm}$. in April, but an overall increase may have been counteracted by the depredations of cormorants. These were mainly responsible for the reduction of stock I and II, and by selecting the larger fish of stock III may have caused a depression of the average size of population. 


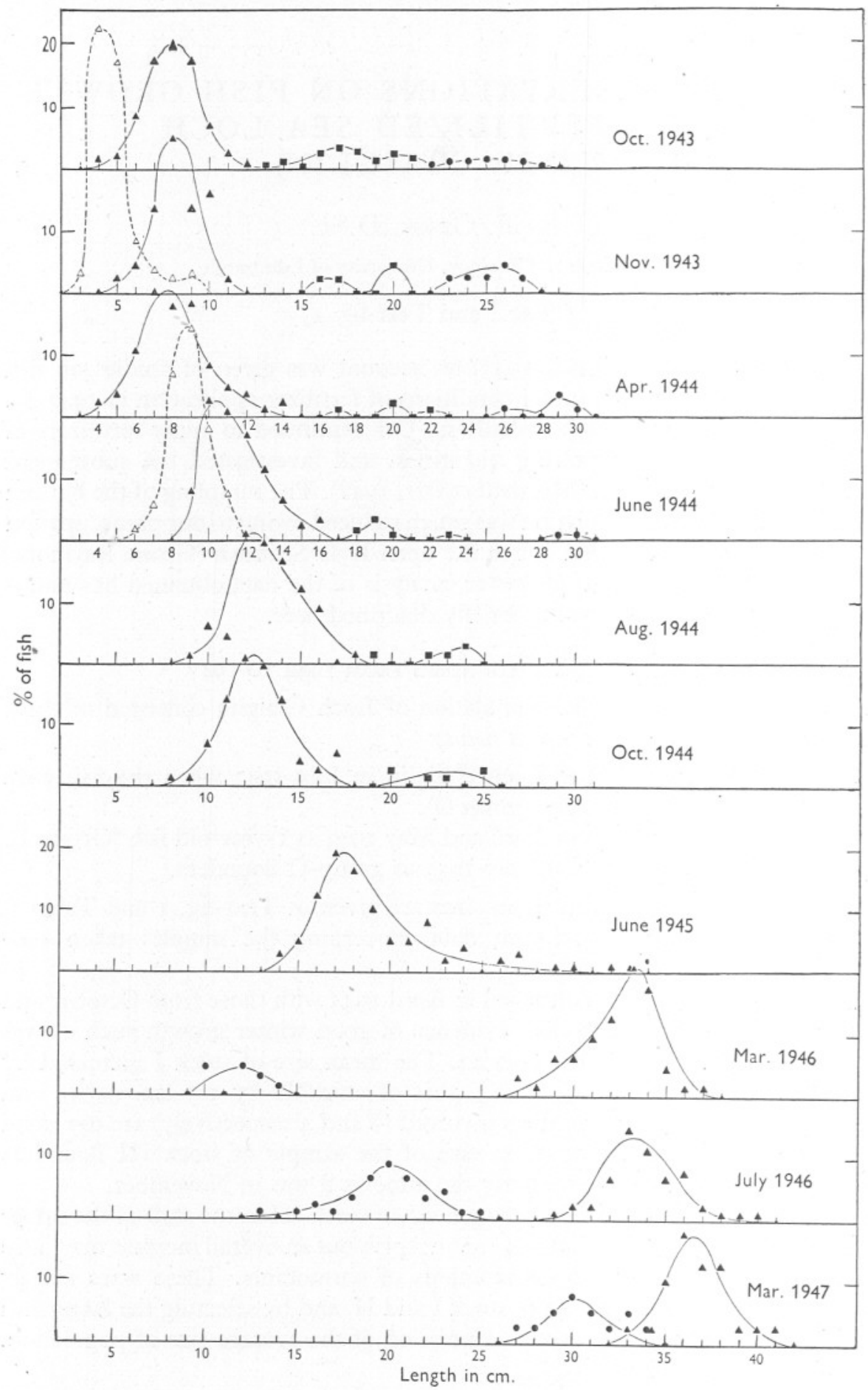

Text-fig. I. The growth of flounders in Loch Craiglin (full lines) and in the estuary of the River Add (broken lines and open triangles). Black triangles refer to stock III, squares to stock II, circles to stock I in $1943 / 4$ and to the native stock in 1946/7. 


\section{Table I. Mean Size and Condition Factor of Flounders FROM LOCH CRAIGLIN}

\begin{tabular}{|c|c|c|c|c|c|c|c|c|c|c|c|c|c|c|c|}
\hline \multirow[b]{2}{*}{$\begin{array}{l}\text { Date of } \\
\text { capture }\end{array}$} & \multicolumn{5}{|c|}{ Stock III } & \multicolumn{5}{|c|}{ Stock II } & \multicolumn{5}{|c|}{ Stock I } \\
\hline & No. & $\begin{array}{l}\text { Age } \\
\text { group }\end{array}$ & $\begin{array}{l}\text { Length } \\
\text { (cm.) }\end{array}$ & $\begin{array}{l}\text { Weight } \\
\text { (g.) }\end{array}$ & $K$ & No. & $\begin{array}{l}\text { Age } \\
\text { group }\end{array}$ & $\begin{array}{l}\text { Length } \\
\text { (cm.) }\end{array}$ & $\begin{array}{l}\text { Weight } \\
\text { (g.) }\end{array}$ & $K$ & No. & $\begin{array}{l}\text { Age } \\
\text { group }\end{array}$ & $\begin{array}{r}\text { Length } \\
(\mathrm{cm} .)\end{array}$ & $\begin{array}{l}\text { Weight } \\
\text { (g.) }\end{array}$ & $K$ \\
\hline $\begin{array}{l}\text { I943: } \\
\text { Oct. } \\
\text { Nov./Dec. }\end{array}$ & $\begin{array}{r}215 \\
34\end{array}$ & $\stackrel{\mathrm{O}}{\mathrm{O}}$ & $\begin{array}{l}7 \cdot 9 \\
8 \cdot 2\end{array}$ & $\begin{array}{l}6 \cdot 8 \\
7 \cdot 3\end{array}$ & $\begin{array}{l}\mathrm{I} \cdot 38 \\
\mathrm{I} \cdot 33\end{array}$ & $\begin{array}{r}45 \\
4\end{array}$ & $\begin{array}{l}\text { I } \\
\text { I }\end{array}$ & $\begin{array}{l}17 \cdot 5 \\
18 \cdot 2\end{array}$ & $\begin{array}{l}66 \cdot 0 \\
68 \cdot 7\end{array}$ & $\begin{array}{l}I \cdot 23 \\
I \cdot I \cdot 4\end{array}$ & $\begin{array}{r}20 \\
6\end{array}$ & I & $\begin{array}{l}25.0 \\
25.4\end{array}$ & $\begin{array}{l}197 \cdot 3 \\
184 \cdot 5\end{array}$ & $\begin{array}{l}I \cdot 26 \\
I \cdot I 3\end{array}$ \\
\hline $\begin{array}{l}\text { I944: } \\
\text { Apr. } \\
\text { June } \\
\text { Aug. } \\
\text { Oct. }\end{array}$ & $\begin{array}{r}75 \\
\text { II } 4 \\
6 \mathrm{I} \\
65\end{array}$ & $\begin{array}{l}\text { I } \\
\text { I } \\
\text { I } \\
\text { I }\end{array}$ & $\begin{array}{r}8.2 \\
11.6 \\
13.0 \\
12.7\end{array}$ & $\begin{array}{r}7.5 \\
16.9 \\
23.0 \\
23.6\end{array}$ & $\begin{array}{l}I \cdot 36 \\
I \cdot 08 \\
I \cdot 05 \\
I \cdot I 5\end{array}$ & $\begin{array}{l}4 \\
8 \\
4 \\
6\end{array}$ & $\begin{array}{l}\text { II } \\
\text { II } \\
\text { II } \\
\text { II }\end{array}$ & $\begin{array}{l}19 \cdot 7 \\
19 \cdot 3 \\
22 \cdot 5 \\
22 \cdot 4\end{array}$ & $\begin{array}{r}88 \cdot 2 \\
72 \cdot 5 \\
114 \cdot 2 \\
122 \cdot 7\end{array}$ & $\begin{array}{l}I \cdot I 5 \\
I \cdot O I \\
I \cdot O O \\
I \cdot I 6\end{array}$ & $\begin{array}{l}6 \\
2\end{array}$ & $\begin{array}{l}\text { II } \\
\text { II }\end{array}$ & $\begin{array}{l}28 \cdot 8 \\
29 \cdot 2\end{array}$ & $\begin{array}{l}259.0 \\
268.5\end{array}$ & $\begin{array}{l}\mathrm{I} \cdot 08 \\
\mathrm{I} \cdot 08\end{array}$ \\
\hline $\begin{array}{l}\text { I945: } \\
\text { June }\end{array}$ & 98 & II & 19.2 & $93 \cdot 3$ & $I \cdot 3 I$ & & & Native st & tock' & & & & & & \\
\hline $\begin{array}{l}\text { Mar. } \\
\text { July }\end{array}$ & $\begin{array}{l}54 \\
52\end{array}$ & $\begin{array}{l}\text { II } \\
\text { III }\end{array}$ & $\begin{array}{l}32 \cdot 3 \\
34 \cdot 0\end{array}$ & $\begin{array}{l}408 \cdot 6 \\
463.0\end{array}$ & $\begin{array}{l}I \cdot 2 I \\
I \cdot I 8\end{array}$ & $\begin{array}{r}9 \\
37\end{array}$ & $\underset{\mathrm{I}}{\mathrm{O}}$ & $\begin{array}{l}\text { Ir. } 8 \\
20.0\end{array}$ & $\begin{array}{l}20 \cdot 0 \\
96 \cdot 1\end{array}$ & $\begin{array}{l}I \cdot 22 \\
I \cdot 20\end{array}$ & & & & & \\
\hline $\begin{array}{l}\text { I947: } \\
\text { Mar./Apr. }\end{array}$ & 26 & III/I & IV 36.8 & 580.0 & $I \cdot I 6$ & I3 & I/II & 30.6 & $353^{\circ} 0$ & $I \cdot 23$ & & & & & \\
\hline
\end{tabular}

The symmetry of the curve relating to the size distribution of the II4 stock III flounders caught in June is even more distorted by the reduction in numbers of the size classes II-I6 cm. than the corresponding curve for the recaptures in April. In contrast to this, the sample of 52 flounders of the same age, caught during the same month in the estuary of the River Add, shows a very symmetrical size distribution around the mean of $8.8 \mathrm{~cm} ., 7.8 \mathrm{~g}$. Therefore the median $(\mathrm{I} 2.5 \mathrm{~cm}$.) might be a more accurate estimate of the growth attained by stock III.

Even so, the size of stock III flounders was much smaller than that of stock I at the same age in June 1943 ( $18.2 \mathrm{~cm}$., 76 g.). The reduction of growth rate was almost certainly due to the deterioration of hydrographic conditions caused by prolonged closure of the dam. The position was aggravated by the distribution on I August I 944 of ten times the usual quantity of fertilizers ( $1344 \mathrm{lb}$. sodium nitrate and $448 \mathrm{lb}$. superphosphate), most of which was taken up by, and converted into, sea weed and Zostera. The lack of circulation, the consequent drastic reduction in oxygen content and the development of high concentrations of $\mathrm{H}_{2} \mathrm{~S}$ in the deep water and of very high $\mathrm{pH}$ values near the surface, recorded by Marshall \& Orr (1948), caused conditions unfavourable for the growth of fish. This continued to be very poor throughout 1944. The growth increment of stock III from June to August was negligible, while from August to October 1944 growth seems to have ceased altogether. The mean value for length was, in fact, a little less in October than in August (Text-fig. I and Table I).

Stock I and II specimens became very scarce in I944. From the few fish (Stock II) obtained it would appear that no growth had taken place from April to June, a slight increase from June to August, and again practically no growth from August to October. The growth increment for the whole year, October 1943 to October 1944, amounted to $4.8 \mathrm{~cm}$., I7 g., in stock III, and 
to $4^{.2 \mathrm{~cm}}$., $54 \mathrm{~g}$., in stock II, and was thus of the same order as that recorded for flounders in natural waters.

During the following autumn and winter (1944/45) the sluice gate of the dam was opened to allow interchange of the water with the main loch outside. This led to an improvement in hydrographic conditions and to a striking improvement in fish growth.

In June I945 a sample of 99 flounders was obtained (Fig. I, Table I). Examination of their otoliths, all of which were removed after the fish had been measured and weighed, showed that with the possible exception of one fish $(27.4 \mathrm{~cm}$.) all belonged to stock III. Their distribution curve is very asymmetrical. Comparison with the previous curves shows that the growth increment of stock III was greater during the period October I944 to June I945 than during the whole of 1944 .

The next sample ( 63 flounders) was caught in March 1946. Of these 54 were 3-year-old stock III specimens. The mode of their size distribution was $33 \mathrm{~cm}$., i.e. $16 \mathrm{~cm}$. greater than in June 1945, a marked improvement over the normal annual growth increment of 4-7 cm. in unfertilized waters. Their growth slowed down again after March I946. By July of that year they had added very little to their size, and by March/April 1947, at an age of 4 years, their modal class reached $36 \mathrm{~cm}$.

The sample of March 1946 contained 9 group-O flounders of a mean size of II $\cdot 8 \mathrm{~cm}$., $20 \mathrm{~g}$. They were obviously 'native' fish which most likely had developed from eggs spawned in Loch Craiglin in 1945. Another sample of 37 of the same native stock, caught the following July, had a mean size of $20.0 \mathrm{~cm}$., $96 \mathrm{~g}$.; and I3 specimens, netted in March/April I947, had attained an average of $30.6 \mathrm{~cm}$., $353 \mathrm{~g}$., a remarkable growth for 2-year-old flounders.

\section{GROWTH OF OTOLITHS}

Examination of the otoliths showed that both the poor growth of the flounders in 1944 and the excellent growth in 1945/46 was clearly recorded by the width of the otolith rings. In 1944, stock III specimens laid on narrow bands similar to fish caught in areas outside Loch Sween (Pl. I, figs. I-4; see also Gross, 1947), while the bands formed in 1945 were broad and strongly plicated (Pl. I, figs. 6, 7). The extremely wide range of size of stock III flounders caught in June 1945 is illustrated by figs. 5 and 6 (Pl. I) which show otoliths of a small ( $14.5 \mathrm{~cm} ., 43 \mathrm{~g}$.) and a very large specimen $(33.0 \mathrm{~cm}$., $408 \mathrm{~g}$.), both belonging to group II. The very rapid growth of the 'native' flounders in 1946 and 1947 , illustrated by three otoliths (Pl. I, figs. 8-I0), represents a marked contrast to that of stock III in I944 (Pl. I, figs. I-4). 

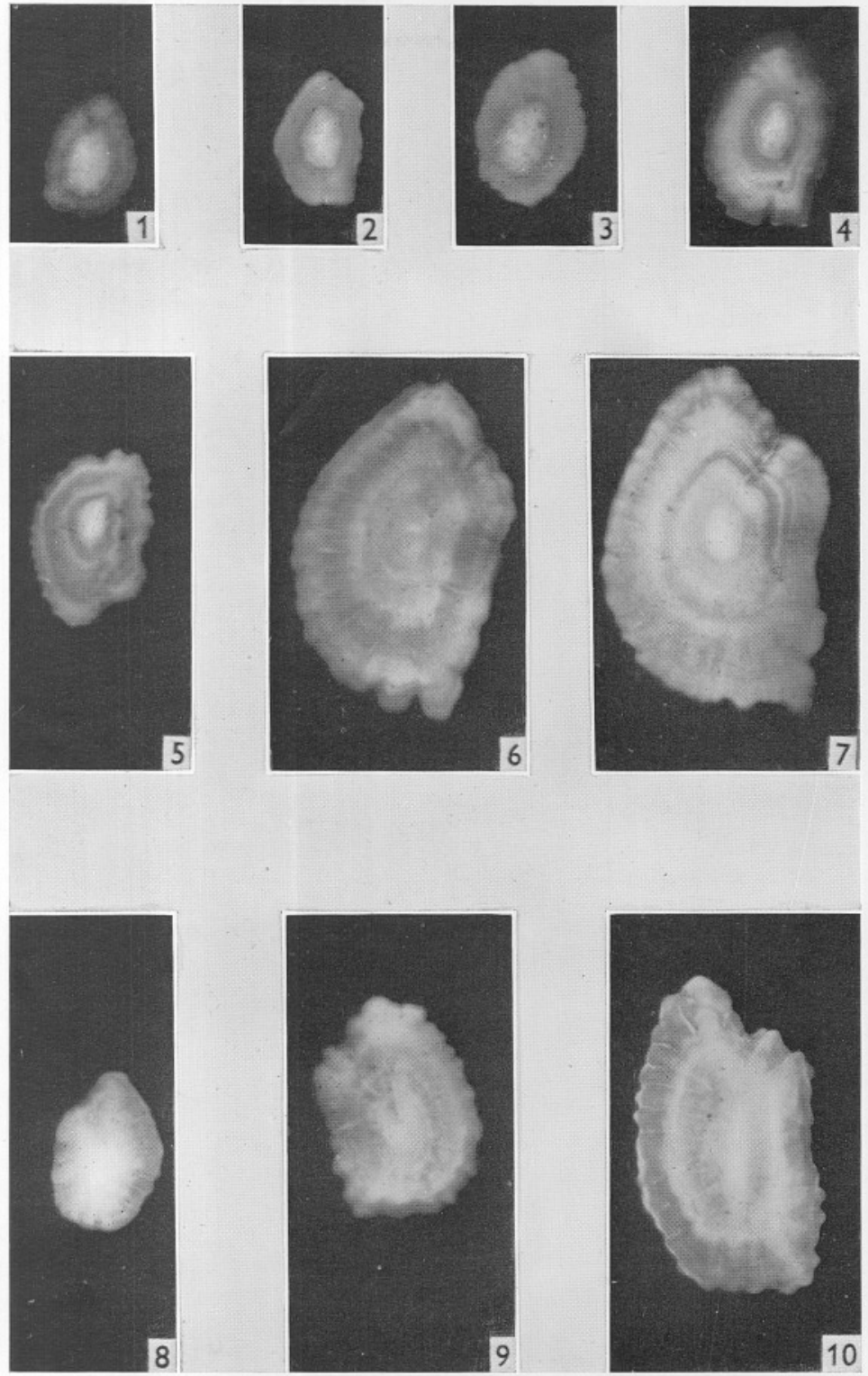

8
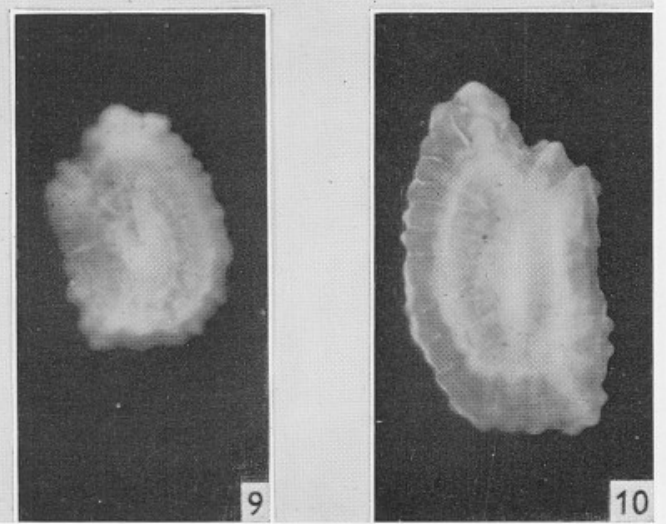

Otoliths of flounders from Loch Craiglin. Magnification of all figures $\times 5.5$.

Fig. I. Group O; caught on I6. x. 43 ; size IO. I cm., II g.

Fig. 2. Group I; caught on Io. iv. 44 ; size $10.8 \mathrm{~cm}$., I4 g.

Fig. 3. Group I; caught on 8. iv. 44 ; size $13.5 \mathrm{~cm}, 28 \mathrm{~g}$.

Fig. 4. Group I; caught on II. X. 44 ; size I7. I cm., $59 \mathrm{~g}$.

Fig. 5. Group II; caught on 5. vi. 45 ; size I $4.5 \mathrm{~cm} ., 43 \mathrm{~g}$.

Fig. 6. Group II; caught on 4. vi. 45 ; size $33.0 \mathrm{~cm} ., 408 \mathrm{~g}$.

Fig. 7. Group II; caught on I5. iii. 46; size $32.2 \mathrm{~cm} ., 354 \mathrm{~g}$.

Fig. 8. Group O; caught on 20. iii. 46 ; size $12.9 \mathrm{~cm}$., $27 \mathrm{~g}$.

Fig. 9. Group I; caught on 8. vii. 46 ; size $23.4 \mathrm{~cm}$., I $45 \mathrm{~g}$.

Fig. IO. Group I; caught on 28. iii. 47 ; size $32 \cdot 9 \mathrm{~cm}$., $457 \mathrm{~g}$. 


\section{CONDITION FACTOR}

Comparison of the relation between length and weight of the flounders, expressed by the condition factor (Table I, $K$; see also Gross, I947) reflects the unfavourable conditions for fish growth in 1944, especially during the summer. Condition factors were as low as $\mathrm{r} .05$ and $\mathrm{I} .08$ in June and August, rising to I. I5 in October. The condition factor of stocks I and II was very low throughout I944. In I945 rapid growth was accompanied by a high condition factor ( $\mathrm{I} \cdot 3 \mathrm{I}$ in June I945). It dropped to I.2I in March I946, to I.I8 in July I946, and to I.I6 in March/April I947. This last, relatively low value may have been correlated with the circumstance that the fish were ripe and may have begun spawning before they were caught. The native stock possessed a fairly high condition factor $(\mathrm{I} \cdot 2-\mathrm{I} \cdot 23)$ in all three samples caught.

\section{Sexual Maturity of the Flounders}

Of the 52 3-year-old stock III flounders obtained in March 1946 all but 3 females were fully mature: all males and some females were 'running ripe', and while the rest possessed fully developed ovaries the eggs did not run out freely when the animals were stripped. The 4-year-old stock III flounders caught in March/April 1947 (II females and I5 males) were all mature, 3 of the females spent. Of the 13 'native' fish, just 2 years old, $I 2$ were males, and II of these were fully mature, I immature, and I was an immature female. Thus the onset of maturity occurred in males at the age of 2 years, in females at the age of 3 .

\section{Discussion}

The observations recorded above represent a postscript to those described and discussed in a previous paper (Gross, 1947) which must be taken into consideration in assessing the growth rate of flounders in manured water as compared with that in natural conditions. The new data are instructive from the point of view of judging the effects of different factors on the growth of flounders. It has been recorded (Marshall, 1947) that a very heavy growth of phytoplankton took place in Loch Craiglin in the spring of 1944, but this did not lead to an improvement in fish growth. The distribution of ten times the usual quantity of fertilizers in August 1944 brought about a disproportionately small increase of phytoplankton crop and marked the beginning of a period of complete cessation of fish growth. There is every reason to believe that fish growth did not slow down and finally stop owing to shortage of food, but because of extremely bad hydrographic conditions consequent upon the prolonged closure of the dam. The growth increment of stock III flounders for the year October I943 to October 1944 amounted to merely $4 \cdot 8 \mathrm{~cm}$., I6.8 g., which is approximately the annual growth increment of flounders in natural waters. 
In 1945, after several months of interchange of water through the open sluice, the chemical and physical conditions in the loch improved, and during the period October 1944 to March 1946 the flounders increased by $19 \cdot 6 \mathrm{~cm}$. $(155 \%)$ in length and by $385 \mathrm{~g}$. ( $1660 \%)$ in weight, a very marked improvement on any records of marine fish growth in natural waters. Fertilizers were applied only on four occasions during that year, all during the period FebruaryApril 1945, $23 \mathrm{lb}$. N and $3.4 \mathrm{lb}$. P being added each time. During I946, fertilizers were applied on two occasions only (superphosphate along with ammonium chloride on one occasion and urea on the other); these had little effect on phytoplankton density (Marshall \& Orr, I948). During the same year the growth of stock III flounders slowed down considerably. The growth increment from March 1946 to March 1947 amounted to only $4.5 \mathrm{~cm}$., I7 I g. On the other hand, the 'native' stock increased during the same period by I $8.8 \mathrm{~cm}$., $333 \mathrm{~g}$., to $30.6 \mathrm{~cm}$., $353 \mathrm{~g}$., at an age of 2 years. They were thus about $5 \mathrm{~cm}$. longer, and I50 g. heavier than stock I flounders at the same age. The slower growth of stock III specimens during I946 may have been due to their sexual maturation and subsequent spawning, and perhaps also to the predominance of Hydrobia, not taken readily by flounders, and the relative scarcity of Cardium and chironomid larvae, favoured by these fish, and especially perhaps by larger specimens.

The new data, in conjunction with the results obtained in $1942 / 43$, lead to the conclusion that distribution of fertilizers can bring about a very great increase in the growth rate of flounders, provided the hydrographic conditions are favourable. Though the last application of fertilizers was made in January 1946, the fertility level represented by the growth of fish remained high throughout I946 and I947, and, though declining, will probably remain above the prefertilization level for some years owing to the regeneration of nutrients locked up in great accumulations of organic material, remains of previous fertilizations.

There seem to be very few records concerning the relation of size, age and sexual development of fish. If maturity is correlated with a certain age and not with size, fish which grow more rapidly under conditions of fertilization would reach a considerable size, well above the minimum limit for marketing, before spawning. The maintenance of fish stocks, on the other hand, depends to a great extent on the size of the breeding stock, i.e. on the number of fish which have spawned before they were caught.

From the few published data it would appear that flounders, like plaice, normally mature at the age of 4-5 years, and that males reach maturity a year earlier than females. Kändler (1932) found that, in I93I, flounders of the Oder Bank reached maturity one year earlier than in 1925, the majority of females at the end of the fourth year, some males already at the end of the third year. He correlates the acceleration of maturity with an increase in growth rate from I925 to I93I, due to thinning out of stock. In the Danzig area and in the central parts of the Baltic the flounders reached maturity at 
a higher age, males at 5 , females at 6 , and the size of the various groups was markedly smaller (Kändler, I932). Molander (I932) investigated the flounder stocks off the Swedish coast in I930/3I and found no spawning females of lesser size than $22 \mathrm{~cm}$. and younger than group IV. Males were ripe at a length of I8-22 cm. and belonged to group III. In previous years spawning males, I3 - I $5 \mathrm{~cm}$. long, were also recorded. These presumably were also group-III flounders which had grown more slowly than those caught in I930/3I.

The fish obtained in Loch Craiglin also provide some useful evidence concerning the relationship between size, age and maturity. In March I946 the great majority of 3-year-olds, both males and females, were fully ripe, and in March 1947 2-year-old males were ready for spawning. Only one 2-year-old female was obtained which was immature. Thus the males, at any rate, under conditions of fertilization and greater abundance of food, have matured at an age of 2 years. The data suggest, therefore, that sexual development in flounders goes with size rather than with age.

\section{SUMMARY}

Flounders grew much more slowly in I 944 than during the previous 2 years. From October I 943 to October I 944 their mean size increased from $7 \cdot 9 \mathrm{~cm}$., $6.8 \mathrm{~g}$., to $12.7 \mathrm{~cm}$., $23.6 \mathrm{~g}$., an increment which was if anything smaller than under normal conditions. The reason for the reduction in growth rate is attributed to the increasingly unfavourable hydrographic conditions resulting from the prolonged closure of the dam, in particular to the high $\mathrm{H}_{2} \mathrm{~S}$ concentration, the high $\mathrm{pH}$ and the low oxygen concentration of the water.

In the autumn of 1944 the sluice gate of the dam was opened for several months. In I945/46 the growth of stock III flounders was very rapid. They reached a mean size of $32.3 \mathrm{~cm} ., 409 \mathrm{~g}$., in March 1946 and $36.8 \mathrm{~cm} ., 580 \mathrm{~g}$., in March/April I947. Native flounders reached a mean size of $30.6 \mathrm{~cm} ., 353 \mathrm{~g}$,, in 2 years.

The poor growth in 1944 was reflected in narrow bands laid on by the otoliths and in low condition factors ( $\mathrm{I} \cdot 05-\mathrm{I} \cdot \mathrm{I} 5$ ), the subsequent great improvement in growth rate was correlated with broad rings and high condition factors (I·3I-I.I6 in stock III, I·2-I·23 in the native stock).

In March 1946 most females and all males were ripe at an age of 3 years. In March/April I947 Io males were fully ripe at 2 years of age. These observations, in conjuction with those recorded by Kändler (I932), suggest that sexual maturity is correlated with size and not with age. 


\section{REFERENCES}

Gross, F., 1947. An experiment in marine fish cultivation: V. Fish growth in a fertilized sea-loch (Loch Craiglin). Proc. Roy. Soc. Edin., B, Vol. LxIII, pp. 56-95.

Gross, F., Raymont, J. E. G., Nutman, S. R. \& Gauld, D. T., I946. Application of fertilizers to an open sea loch. Nature, Vol. I58, p. I87.

KäNDLER, R., I932. Veränderungen im Flundernbestand der Ostsee durch die Fischerei. Cons. Perm. Int., Rapp. et Proc.-Verb., Vol. LxxvIII (III), pp. I-45.

Marshall, S. M., I947. An experiment in marine fish cultivation: III. The plankton of a fertilized loch. Proc. Roy. Soc. Edin., B, Vol. LxIII, pp. 2I-33.

MARHSAlL, S. M. \& ORR, A. P., I948. Further experiments on the fertilization of a sea loch (Loch Craiglin). The effect of different fertilizers on the phytoplankton. Fourn. Mar. Biol. Assoc., Vol. xxvir, pp. 360-79.

Molander, A. R., I932. Der Flunderbestand in der südlichen Ostsee und der Einfluss, den die Fischerei auf ihn ausübt. Cons. Perm. Int., Rapp. et Proc.-Verb., Vol. LXXviII (v), pp. I-I5. 